\title{
The Origins of the Conflict Between Malenkov and Zhdanov: 1939-1941
}

Over twenty years ago Merle Fainsod warned against underestimating the "fluid play of bureaucratic politics" in the Stalinist political system. However, scholars have generally regarded the Secretariat of the Central Committee (CC) of the VKP(b) as immune to this process during Stalin's reign as general secretary. They have assumed either that Stalin did not permit conflict between the directors of the various bureaucratic divisions in the Secretariat or that such conflict could simply not develop in the leading organ of the party's apparat.

This study seeks to show that the Secretariat was not monolithic and that its leaders were embroiled in a fundamental dispute over priorities and over the proper relationship between Communist Party officials and those Communists who staffed the state structure. In fact, the well-known conflict between Andrei Zhdanov and Georgi Malenkov, who, as secretaries of the $\mathrm{CC}$, directed or supervised the two main bureaucratic divisions of the Secretariat from 1939 until 1948, emerges as a classic illustration of this kind of disputation. In the opening phase of the rivalry, which began after the Eighteenth Congress of the VKP(b) in March 1939, each secretary's conception of priorities was closely linked to his bureaucratic responsibilities. At the same time, the dispute was directly influenced by the Soviet leadership's changing definition of the Secretariat's immediate objectives.

Few studies of the Stalinist political system have explicitly pointed out that the perennial bureaucratic reorganizations of the Secretariat in the 1930s reflected shifts in Stalin's views. It was, however, Stalin's changing definition of the Secretariat's proper role that provided the basis for the conflict between Zhdanov and Malenkov. Although Stalin claimed that party officials should "combine economic and party-political work,"1 he periodically demanded that they shift emphasis from one sphere of activity to the other. These shifts influenced the organization of the Secretariat and the relationship between the Secretariat and the Council of People's Commissars (Sovnarkom). In order to give priority to "party-political work," Stalin called for the establishment of

1. "Economic work" refers to the supervision and direction of production while "party-political work" refers to the recruitment, placement, and education of personnel, the development of effective party organization, improved intraparty communication, and monitoring performance of other party members. Some leaders used the term "internal party work" to refer to these activities. 
"functional" departments in the Secretariat and thereby permitted the Sovnarkom greater autonomy in industrial management. In contrast, when Stalin sought to emphasize the Secretariat's "economic work" he urged the creation of "production branch" departments within the Secretariat and thereby limited the Sovnarkom's autonomy.

In his report to the Sixteenth Congress of the VKP(b) in mid-1930, Stalin implied that the Secretariat should focus on "party-political work" and that the Sovnarkom, directly supervised by the Politburo, should enjoy primary responsibility for industrial administration. In order to assure this division of labor, Stalin approved the formation of "functional" departments for personnel management, cadre education, and supervision of the fulfillment of existing decrees within the Secretariat; dramatized the Sovnarkom's industrial responsibilities in a number of public addresses; and, in December 1930, increased the number of Politburo members with responsibilities in the Sovnarkom (the Politburo commissars). ${ }^{2}$

In early 1934, however, Stalin found fault with this division of labor in his address to the Seventeenth Congress of the $\operatorname{VKP}(b)$. He charged that "functionalism" hindered industrial development and urged the Secretariat to focus on "economic work" and to provide more "concrete leadership" of industry. Further, he approved the establishment of "production branch" departments to improve the Secretariat's ability to supervise and intervene in the Sovnarkom's industrial administration. ${ }^{3}$ Three years later Stalin again dramatically reversed himself. In early 1937 he told the CC that party officials had become preoccupied with "economic work" and had neglected "partypolitical" work. He called for greater attention to the theoretical education of party members, which he described as the "mastery of Bolshevism."4 Finally, in his report to the Eighteenth Congress of the VKP(b) in March 1939, Stalin once again stressed the primacy of "party-political work" as he had in 1930. He called for the establishment of two "functional" directorates (upravlenie) to deal with the theoretical education of party members and personnel management, and implied as before that the Sovnarkom should enjoy primary responsibility for the administration of industry.

Both Zhdanov and Malenkov drew heavily on Stalin's formulations in outlining their own conceptions of the Secretariat's proper role and priorities.

2. These Secretariat departments were established in January 1930. See Istoriia KPSS, vol. 4, book 2 (Moscow, 1971), p. 34. Stalin praised the new departments in his address to the Sixteenth Congress. See J. Stalin, Works, vol. 12 (Moscow, 1952-55), pp. 336-38. For Stalin's endorsement of the Sovnarkom's industrial role, see Stalin, Works, vol. 13, pp. 34-52. In December 1930, V. Molotov, V. Kuibyshev, and S. Ordzhonikidze were given major Sovnarkom responsibilities. See Politicheskii slovar' (Moscow, 1940), pp. 298, 352, 395.

3. Stalin, Works, vol. 13, pp. 374-75. 211-20.

4. I. Stalin, Sochineniia, ed. Robert H. McNeal, vol. 1 (14) (Stanford, 1967), pp. 
Zhdanov presented his views in his report to the Eighteenth Congress in March 1939, and Malenkov outlined his views in his report to the Eighteenth Conference of the VKP(b) in February 1941.

Zhdanov stressed the primacy of "party-political" work and therefore drew heavily on Stalin's address to the CC in early 1937 and his report to the Eighteenth Congress. Although Zhdanov considered all components of "party-political work" significant, he particularly emphasized the Secretariat's supervision and direction of party members' theoretical education which was to be based on "independent study" of the Kratkii kurs (Short Course) and other materials. Zhdanov sought to limit the Secretariat's "economic work" by circumscribing party officials' means to intervene in the Sovnarkom's industrial administration and by supporting the "functional" organization of the Secretariat approved by the Eighteenth Congress.

Zhdanov's stress on "party-political work" reflected his conception of the Secretariat's leadership of the VKP(b). Zhdanov apparently believed that the Secretariat could lead the party most effectively by concentrating on the recruitment, assignment, education, and monitoring of individual party members. If the Secretariat dealt with these matters successfully, the Communists who manned the state structure would not need constant Secretariat interference (derided as "petty tutelage"). Party officials would then be free to supervise and coordinate a wide range of social, economic, and other activities, thus providing "political leadership" for the society as a whole.

Malenkov, on the contrary, gave primacy to the Secretariat's "economic work" and therefore drew heavily on Stalin's address to the Seventeenth Congress of the $\operatorname{VKP}(\mathrm{b})$ which called on the Secretariat to provide industry with "concrete guidance." Although Malenkov was deeply involved in personnel management, he had little sympathy for certain other components of "party-political work," particularly for the formal study of MarxistLeninist texts. Malenkov gave highest priority to the Secretariat's supervision and intervention in the Sovnarkom's industrial administration, and during 1939-41 he sought to restore the "production branch" departments which had been created in 1934 and dismantled in 1939. In his report to the Eighteenth Conference of the VKP(b) in 1941, Malenkov implied that theoretical study had little importance for effective industrial management and recommended the appointment of a large number of specialized secretaries for industry and transport to improve the Secretariat's supervision and participation in the Sovnarkom's industrial administration.

Malenkov's ordering of priorities also reflected his basic conception of the Secretariat's role. He clearly regarded concentration on "party-political work" as insufficient for the Secretariat to lead the party as a whole. For Malenkov, "political leadership" was apparently far too abstract a concept; he insisted on Secretariat "leadership of the economy" which meant the 
party officials' active intervention in the solution of immediate production problems.

In his report to the Eighteenth Congress, Stalin had implied that the Secretariat should focus on "party-political work." He declared that Engels's prognosis about the "withering away" of the state was incorrect and insisted that the Soviet state should play a central role in economic development. Stalin's formulations concerning the state implied that the Sovnarkom should play a major role in industry and were endorsed by the Politburo commissars who dominated the Sovnarkom. ${ }^{\mathbf{5}}$

In his discussion of the $\operatorname{VKP}(\mathrm{b})$, Stalin focused on two central components of "party-political work": the theoretical education of party members and personnel management. He insisted that mastery of Marxist-Leninist theory was essential for success in every field and that improved personnel management was critical to the implementation of the party's policies. He called for the establishment of a single directorate of cadres (upravlenie kadrov) with subordinate departments at the republic, krai, and oblast levels and a similarly organized agitprop directorate (upravlenie propagandy $i$ agitatsii) to improve work in these two spheres. ${ }^{6}$

Apparently following Stalin's lead, Zhdanov outlined his own preference for "party-political work" in a report on the new party rules. Zhdanov insisted that theoretical education of party members was the key to the VKP(b)'s success in assuring the "transition to communism" which had ostensibly begun at the Eighteenth Congress. He repeatedly asserted that the study of Marxist-Leninist theory, as embodied in the Kratkii kurs and other materials, would provide party members with the "perspective" vital for practical success. He also interpreted Stalin's report as sanctioning a limitation of the Secretariat's capacity to engage in "economic work." Stalin had implied that the "production branch" departments had hindered effective personnel management and Zhdanov called for their abolition, a reform which would have seriously weakened local party officials' control over industry. But Zhdanov sought to limit rather than eliminate the Secretariat's "economic work." $\mathrm{He}$ announced that henceforth the primary party organizations (PPO) in factories would enjoy the right to monitor the performance of the factory manager (pravo kontrolia). ${ }^{7}$

Zhdanov's effort to define the "correct combination of economic and party-political work" at the enterprise level set the stage for subsequent conflict over the extent of PPO responsibilities vis-à-vis the factory manager who

5. For Stalin's discussion of the Soviet state see XVIII $s^{\prime \prime} e z d V K P(b)$ : Stenograficheskii otchet (Moscow, 1939), p. 35. For comments by the Politburo commissars see pp. $144-45,212,268,397,500$.

6. Ibid., pp. 30-31.

7. Ibid., p. 533. At this juncture the term kontrol" referred to the "verification of 
was subordinate to a particular People's Commissariat. Zhdanov declared that the PPO should be concerned with all aspects of party work, but he also seemed to imply that the PPO would enjoy full responsibility for "partypolitical work" and the factory manager would enjoy final responsibility for the "economic work" of the plant. Zhdanov outlined managerial prerogatives in broad terms, insisting that constant consultation between management and PPO would not undermine the managers' final authority, and explicitly endorsed the principle of edinonachalie (one-man management) ${ }^{8}$ which implied support for central Sovnarkom direction of industry. He urged PPO leaders to develop detailed working knowledge of plant activity, in order to provide recommendations which would improve production, and demanded that managers cooperate with the PPO and party aktiv within the plant, but he also made it clear that $\mathrm{PPO}$ "economic" responsibilities were limited. He warned PPO leaders "not to take upon themselves the unwarranted functions of direction (rukovodstvo) of economic affairs, assuming the duties of economic administrative bodies and detracting from their responsibilities."' Malenkov, it should be noted, failed to endorse Zhdanov's formulations in his report on behalf of the Credentials Commission. ${ }^{10}$

Zhdanov's conception of the Secretariat's role was incorporated into the party rules approved by the Eighteenth Congress. The VKP (b) was said to be "guided by Marxist-Leninist theory" in all its activity and all party members were obliged to "work indefatigably on raising their political consciousness, on the mastery of the fundamentals of Marxism-Leninism." The central and local industrial and transport departments of the Secretariat were dismantled, and PPOs in enterprises were granted pravo kontrolia. ${ }^{11}$

Both Zhdanov and Malenkov had gained prominence in their respective specialties in the late 1930s, but Central Committee publications do not provide any evidence of conflict between them until after they had assumed the leadership of the two bureaucratic divisions created by the Eighteenth Congress. ${ }^{12}$

fulfillment" of existing decrees. See Politicheskii slovar', p. 277. However, the meaning of the term immediately became a matter of intense dispute within the Soviet leadership.

8. Zhdanov declared that edinonachalie embraced "the capacity to direct, to organize affairs, select cadres, issue appropriate orders, demand reports on completed work, eliminate irresponsibility and divided responsibility." Ibid., p. 535.

9. Ibid., p. 533.

10. Ibid., pp. $146-50$.

11. KPSS v rezoliutsiiakh $i$ resheniiakh $s^{\prime \prime} e z d o v$, konferentsii $i$ plemtmov $T s K$ $V K P(b)$, 8th ed., vol. 5, pp. 381-82, 395.

12. In January 1936, Zhdanov was implicitly recognized as Stalin's leading expert on party history. At that time all CC journals published a critique of history texts, which Zhdanov had written with Kirov and Stalin in 1934, and a resolution naming Zhdanov the head of a commission to study Soviet history texts. See Bol'shevik, 1936, no. 3, for 
Immediately after the Eighteenth Congress, Malenkov became a secretary of the CC, a member of the Orgburo, and director of the new cadres directorate. In the latter capacity he apparently held responsibility for supervising industry as well as for personnel management. The new cadres directorate absorbed personnel from the dismantled "production branch" departments while its own local departments (otdel kadrov) which were headed by secretaries, provided "exacting supervision" of assigned personnel. Moreover, Malenkov soon became personally involved in detailed inspection of industrial activity. ${ }^{13}$

Simultaneously, Zhdanov, who had been the leader of the Leningrad party organization and secretary of the CC since 1934, and responsible for Marxist-Leninist education since 1938, became a member of the Orgburo, a full member of the Politburo, and director of the newly formed agitprop directorate. The agitprop directorate was responsible for all political education and press activities. Its local departments, headed by secretaries, were responsible for training lecturers and other agitprop personnel, for supervising the press, and for both aiding and monitoring party members engaged in "independent study."

Although Stalin and the two junior secretaries did not publicly discuss Secretariat priorities in the period between the Eighteenth Congress and the Eighteenth Conference, Central Committee publications provide indirect evidence of the conflict between Zhdanov and Malenkov and of the Soviet leadership's shifting definition of party priorities. In particular, Partiinoe stroitel'stvo (PS) generally championed Malenkov's position; Bol'shevik usually supported Zhdanov's views; Pravda's editorials, its pictorial coverage of Soviet officials, and CC and Politburo resolutions reflected the relative

these materials. In March 1936 Malenkov replaced Ezhov as the editor of the CC journal Partiinoe stroitel'stvo (see nos. 5 and 6 of 1936). (Partiinoe stroitel'stvo hereafter cited as PS.) This may have indicated that Malenkov replaced Ezhov as the director of the secret cadres department of the Secretariat. See Leonard Schapiro, The Communist Party of the Soviet Union (New York, 1971), p. 407. A comparison of PS and Bol'shevik in the late 1930s reveals no apparent difference in Zhdanov's and Malenkov's discussions of Secretariat work before 1939.

13. It is impossible to determine whether Malenkov was assigned the task of supervising industry or took it upon himself. Whatever the case, the journal he edited began to call for increased Secretariat "direction" of the economy soon after the Eighteenth Congress. "Vpered k kommunizmu," $P S, 1939$, no. 9, p. 9. Although Schapiro concludes that Malenkov became involved in industrial supervision "after 1939" (Schapiro, Communist Party, p. 447), there is some evidence of his personal involvement in industrial supervision in 1939. See Pravda, February 18, 1941. For a detailed discussion of the cadre directorate's structure see $P S, 1939$, no. 13.

14. The agitprop directorate's structure and responsibilities had already been outlined in a CC resolution of November 1938 on the correct use of the Kratkii kurs. See KPSS v resoliutsiiakh . . , 7th ed., vol. 3, pp. 316-25. 
support for the rival secretaries within the Soviet leadership. ${ }^{15}$

From 1939 to 1941, while the two major divisions clashed over the "correct combination of economic and party-political work," the Soviet leadership shifted its support from one set of Secretariat priorities to the other. Zhdanov's views enjoyed sustained leadership support from the Eighteenth Congress until shortly after the outbreak of World War II. Malenkov's views were given sustained support from October 1939 until the end of the USSR's war with Finland and again after the breakdown of Soviet-German relations in the fall of 1940 .

The timing of these shifts suggests that official definition of Secretariat priorities was influenced by changes in the international political system. In particular, severe threats to Soviet security seemed to undermine support for Zhdanov's orientation in Stalin's Politburo.

The Politburo selected by the Eighteenth Congress was dominated by two groups of officials: the CC secretaries who led the Secretariat and the Politburo commissars who led the Sovnarkom. ${ }^{16}$ It seems likely that in the aftermath of the Eighteenth Congress at least some Politburo commissars supported Zhdanov's emphasis on the Secretariat's "party-political work" in order to protect the Sovnarkom from Secretariat interference. Zhdanov's opposition to the "production branch" departments and his support for edinonachalie may have helped to forge an alliance against Malenkov's efforts to extend Secretariat controls in industry. Although the Politburo commissars may well have disagreed over economic priorities, they were probably willing to band together to protect Sovnarkom prerogatives. However, Zhdanov's alliance with the Politburo commissars was apparently undermined by the need to accelerate Soviet defense production in the face of threats to the USSR's security. The formal study of Marxism-Leninism and the PPO's limited supervision of industrial activity advocated by Zhdanov were apparently ineffective in increasing production. Moreover, the Sovnarkom's perennial inability to overcome production problems may well have undermined the Politburo commissars' capacity to defend Sovnarkom autonomy in the industrial field. In this context, the Soviet leadership endorsed Malenkov's view of the Secretariat's role as the most effective means to accelerate defense production.

15. Partiinoc stroitcl'stvo (PS) was edited by the leaders of the cadres directorate until its demise in 1946. Malenkov was editor in chief from March 1936 until late 1940. Although Zhdanov was not listed as a member of Bol'shevik's editorial board, at least two of his deputies were on the board from 1939 onward. Zhdanov's successor as director of the directorate, G. F. Aleksandrov, served on the board from 1939 until the late 1940s.

16. See Politicheskii slovar', p. 429. The secretaries of the CC included Stalin, Andreev, and Zhdanov. The Politburo commissars included Voroshilov, Kaganovich, Mikoyan, and Molotov. Kuusinen and Khrushchev did not fall into either category. 
Immediately after the Eighteenth Congress the two major Central Committee journals began to clash over Secretariat priorities. While the agitprop organ declared that the theoretical education of all party members should be the Secretariat's highest priority, the cadre division organ implied that correct practice and experience in problem solving was the only basis for action and insisted that work with personnel and "direction of the economy" deserved highest priority. ${ }^{17}$

But Pravda's editorials indicated that the Soviet leadership endorsed Zhdanov's orientation, ${ }^{18}$ particularly after a Central Committee meeting in May 1939.19 Pravda gave Zhdanov's report on the CC meeting to the Leningrad party organization front page coverage, and endorsed both his views on the significance of theoretical education and his definition of the "correct combination of economic and party-political work" at the enterprise level. ${ }^{20}$ During this period Malenkov was not generally shown with other leading officials in public. ${ }^{21}$

In this context, the agitprop leadership seemed to become even more assertive in pressing its view of Secretariat priorities. In early August Bol'shevik combined its usual claim that theoretical education was the basis for all success with a sharp criticism of those party members who ostensibly neglected theoretical study because of their preoccupation with "practical" work. ${ }^{22}$ Moreover, the agitprop leaders' views were now incorporated into CC resolutions. A CC resolution of August 16, 1939 sharply condemned local

17. Cf. "Velichestvennaia programma bor'by za kommunizm," Bol'shevik, 1939, no. 8, p. 5, approved for publication April 29, 1939, with "Vpered k kommunizmu," PS, 1939, no. 9, p. 9, approved for publication April 27, 1939.

18. Pravda, March 30, 1939; April 3, 1939; April 11, 1939; April 22, 1939. In light of this support for Zhdanov, the cadre directorate journal published an article by his deputy, G. F. Aleksandrov, extolling the virtues of Marxism-Leninism. G. F. Aleksandrov, "Bol'sheviki obiazany znat' zakony razvitiia obshchestva," $P S, 1939$, no. 9, approved for publication April 27, 1939.

19. There is some indication of a brief period of leadership support for Malenkov's orientation in early May 1939. On the one hand Malenkov seemed to enjoy a favored position at the May Day parade of 1939 (Pravda, May 1, 1939), and a CC resolution published that month seemed to embody his views on Secretariat industrial responsibility. (See an undated and shortened version in $P S, 1939$, no. 10, p. 62.) On the other hand, Pravda did not endorse his position editorially, and resumed its support for Zhdanov's views in mid-May. See Pravda, May 17, 1939; May 18, 1939; May 19, 1939; May 21, 1939. Moreover, there is some indirect evidence that Malenkov lost influence at the CC meeting later that month. Pravda, May 26, 1939; June 1, 1939.

20. Pravda, June 3,1939 ; June 6,1939 ; June 7,1939 ; June 15, 1939 ; July 20,1939 ; July 21, 1939.

21. Malenkov did not appear with other officials to mark Physical Culture Day. Pravda, July 19, 1939. Zhdanov received front page coverage on the following day. Pravda, July 20, 1939. Malenkov reappeared in public with other officials at the Supreme Soviet meeting which ratified the Nazi-Soviet pact. Pravda, August 29, 1939; September 1, 1939.

22. "Bol'she organizovannosti v propagandistskoi rabote," Bol'shevik, 1939, no. 11/12, approved for publication August 7, 1939. 
party officials for neglect of theoretical education and failure to monitor their own subordinates' ideological development. ${ }^{23}$ In the face of such indications of leadership support for Zhdanov's views, $P S$ seemed to slacken its campaign to turn the Secretariat to production problems. Instead, the journal focused on the cadre directorate's work with personnel, ignored its industrial activity, and even briefly admitted that Marxist-Leninist theory was a "guide to action." 24

Stalin undoubtedly realized that the Nazi-Soviet pact provided the basis for the German attack on Poland in September 1939, but it is difficult to determine whether or not he expected war between Germany and France and Great Britain. ${ }^{25}$ Whatever his hopes and fears, the Soviet leadership did expand the Secretariat's means for intervention in industrial management in order to accelerate defense production in the first two months after the invasion of Poland.

The first clear indication that the leadership had adopted Malenkov's conception of the Secretariat's proper role appeared in a Pravda editorial in October. On October 17, 1939 Pravda implied that both local party officials and PPO secretaries should play a more active role in the solution of immediate production problems. Pravda criticized local party officials who had "not understood" that the Eighteenth Congress had in fact increased their responsibilities for industrial performance, condemned obkom officials in steelmaking regions for neglecting acute problems of raw materials shortages, and praised PPOs for solving technical problems without waiting for orders from the factory manager. ${ }^{20}$

Later that month, Malenkov's views were embodied in a $\mathrm{CC}$ resolution on production failures in the critical Donbas region. The $\mathrm{CC}$ resolution of October 23, 1939 condemned obkom and gorkom officials for their ostensible neglect of serious shortcomings in coal production-the officials were criticized for ignoring low labor productivity, for ignoring the ineffectiveness of existing work norms and wage scales and the miners' alleged hostility toward new technology, and for failing to help the PPOs use their pravo kontrolia

23. $P S, 1939$, no. 15, p. 62. For Bol'shevik's commentary on the resolution see "Protiv samoteka v propagande marksizma-leninizma," Bol'shevik, 1939, no. 15/16, pp. 53-57, approved for publication September 11, 1939. For a vigorous defense of theoretical education based on the Kratkii kurs see "Moguchee oruzhie bol'shevizma," Bol'shevik, 1939, no. 17, approved for publication September 28, 1939.

24. For a grudging acknowledgment of the importance of Marxism-Leninism see "Marksistskaia leninskaia teoriia-velichaishchaia organizuiushchaia sila," $P S, 1939$, no. 17/18, pp. 8-9, approved for publication October 5, 1939. For an example of the shift in $P S$ 's orientation see N. Patolichev, "O sochetanii partiino-politicheskoi i khoziaistvennoi raboty," $P S, 1939$, no. 14, pp. 33-36, approved for publication August 5, 1939.

25. Cf. David Dallin, Sovict Russia's Foreign Policy: 1939-1942 (New Haven, 1942), pp. 66-67, with Adam Ulam, Stalin (New York, 1973), pp. 510-13.

26. Pravda, October 17, 1939. 
to good effect. The CC resolution ordered the obkomy in the Donbas region to establish coal departments headed by second secretaries to assure more effective Secretariat supervision and intervention. ${ }^{27}$ At the same time the cadre directorate's journal renewed and intensified its campaign to extend the Secretariat's industrial role throughout the country. ${ }^{28}$

Support for Malenkov's orientation was reflected in Pravda's pictures of Stalin's ruling group. Although Zhdanov had appeared with Malenkov in early November 1939, Zhdanov did not appear in Pravda's pictures of the ceremonies and parade marking the anniversary of the Bolshevik Revolution. In contrast, Malenkov was shown as a member of Stalin's inner circle of the moment. ${ }^{29}$ The same day Pravda endorsed Malenkov's view that "practice" was central to party members' education. ${ }^{30}$ Two days later Pravda announced the establishment of coal departments in Donbas obkonny in order to "improve the party's direction of industry" and the PPO's pravo kontrolia. ${ }^{31}$

Most important, the Soviet leadership now restored the local industrial departments which had been dismantled by the Eighteenth Congress. A Politburo decree of November 29, 1939 ordered the restoration of industrial departments in the CC of all republic parties, and in all local party organizations (kraikom, obkom, and gorkom) in order to "strengthen the party's direction of industry and transport" and to help the PPO implement their pravo kontrolia. ${ }^{32}$ While the central production branch departments were not restored until after Zhdanov's death in 1948, this reform was a major victory for Malenkov's definition of Secretariat priorities.

Whatever Zhdanov's reaction to the restoration of the industrial departments which he had attacked in March 1939, his capacity to sustain support for his own conception of Secretariat priorities was probably hampered by his involvement in the USSR's war with Finland. Zhdanov reportedly had been an ardent advocate of the war against Finland ${ }^{33}$ and his political fate was

27. KPSS v rezoliutsiiakh. . , 8th ed., vol. 5, pp. 419-22.

28. "Za usilenie partiinogo rukovodstva promyshlennosti," $P S, 1939$, no. 19, approved for publication October 20,1939, the same day as the CC resolution.

29. Both secretaries appeared in public together in early November but were not named. Pravda, November 1, 1939; November 4, 1939. Malenkov seemed to appear in the center of the group of officials attending the anniversary celebrations at Red Square. Pravda, November 9, 1939. He was shown walking with Stalin and others to Red Square in Pravda, November 10, 1939.

30. Pravda, November 10, 1939.

31. Pravda, November 12, 1939.

32. KPSS v resoliutsiiakh ..., vol. 5, p. 423. This resolution was not published until 1971. However, Pravda's editorial of December 7, 1939 provided oblique references to the decree. Subsequent comment on the decrees of October and November assert that they were designed to improve defense production. See KPSS v rezoliutsiiakh . . ., vol. 5 , pp. 419 and 423.

33. Max Jakobson, The Diplomacy of the Winter War (Cambridge, 1971), p. 145. 
influenced by the military situation at the front. Once it had become clear that the forces of the Leningrad military district would not easily overcome Finnish resistance, Zhdanov was temporarily deprived of his authority as a leading spokesman on Marxism-Leninism. His temporary eclipse was particularly evident in December 1939 when CC publications featured a symposium of essays by Stalin's "closest comrades in arms" to mark his sixtieth birthday. While Malenkov wrote of Stalin's "brilliant contributions" to cadre management, ${ }^{34}$ not a single article by Zhdanov appeared in this collection. Nor did Zhdanov join Malenkov and other officials to mark the anniversary of Lenin's death in January 1940. Furthermore, A. S. Shcherbakov, the leader of the Moscow party organization, temporarily assumed Zhdanov's role as a leading spokesman on theory. Shcherbakov proved to be no supporter of Zhdanov's orientation; his article in the Stalin symposium and his address on the anniversary of Lenin's death failed to support Zhdanov's views that MarxismLeninism was the sole basis for action and that theoretical education of cadres deserved highest priority. ${ }^{35}$ In accord with this erosion of support for the agitprop leadership, Bol'shevik temporarily muted its usual enthusiasm for theoretical education of cadres as the basis for all practical success. ${ }^{36}$

Although Zhdanov was restored to favor at the end of the Finnish war in March 1940, he was no longer able to win sustained leadership support for his conception of Secretariat priorities. Even though Pravda published a series of editorials in February and March endorsing his views on the importance of theoretical education for all cadres and on the proper relationship between local party officials and factory directors, ${ }^{37}$ his views were not incorporated into CC and Politburo resolutions as they had been previously. There is some evidence, however, that Zhdanov endorsed an extension of the authority of the Politburo commissars in order to balance the powers of the newly reconstructed industrial departments. The March 1940 CC meeting which restored Zhdanov to favor ${ }^{38}$ also approved a reform of the Ekonomsovet, composed of the chairman and vice-chairmen of the Sovnarkom, which had increased its capacity to coordinate and direct the industrial commis-

Zhdanov appeared with Voroshilov and Kuusinen at the signing of a treaty between the USSR and Kuusinen's Communist-led "government." Pravda, December 3, 1939.

34. G. Malenkov, "Stalin on Cadres," Stalin (New York, 1940), pp. 117-18.

35. A. Shcherbakov, "The VKP(b)-An Impregnable Fortress," Stalin, pp. 167-68; Pravda, January 22, 1940.

36. "Leninsko-stalinskii put' k kommunizmu," Bol'shevik, 1940, no. 2, pp. 2-6, approved for publication January 19, 1940.

37. Pravda, February 11, 1940; February 13, 1940; February 24, 1940; March 2, 1940. These editorials appeared as Soviet troops overcame Finnish resistance. See Jakobson, Diplomacy of the Winter War, p. 225.

38. The March $\mathrm{CC}$ meeting approved the handling of the war. Two days later Zhdanov reported to the Supreme Soviet on the new territories incorporated into the USSR. Pravda, March 30, 1940; April 1, 1940. 
sariats. ${ }^{39}$ On the eve of the announcement of the reform, Pravda published an editorial which not only stressed the state's control over factory directors and extolled the principle of edinonachalie, but also explicitly quoted Zhdanov's report to the Eighteenth Congress warning the PPOs to limit their "economic work." 40

But the proponents of greater Secretariat intervention were not easily cowed. $P S$ continued to press for the intervention of local party officials in industrial enterprises and Pravda published an editorial in May 1940 which not only defined PPO pravo kontrolia in extremely broad terms but also totally ignored Zhdanov's strictures against undermining factory administration. ${ }^{41}$

The fall of France had an immediate impact on the Soviet leadership's definition of Secretariat priorities. In June 1940, Soviet leaders decided to mobilize the nation for the possibility of a conflict with Germany. ${ }^{42}$ As the Soviet press called for the strengthening of the "economic and defense powers of the Soviet state," state officials were given new authority over both labor and management. In late June, working hours were extended and job transfers prohibited without express permission of enterprise directors; in September the People's Commissariat for State Control was established to bolster "state discipline" and assure the implementation of all governmental decrees, while in October 1940 the control of the People's Commissariats over the training and mobility of the labor force was vastly increased. ${ }^{43}$

In July 1940 a CC resolution demanded that all party organizations assure the implementation of the June decree on labor discipline. ${ }^{44}$ As a result both divisions of the Secretariat modified their definition of Secretariat priorities; $P S$ not only muted its previous campaign for an extension of Secretariat "economic work" but also temporarily endorsed edinonachalie and narrowed its definition of pravo kontrolia. PS also recognized Sovnarkom authority by emphasizing the need for "state" as well as "party discipline."45

39. Julian Towster, Political Power in the USSR: 1917-1947 (New York, 1948), pp. 282-83. For Pravda's comment on the reform see Pravda, April 18, 1940.

40. Pravda, April 16, 1940.

41. N. Volodin, "Rol' partorganizatsii v likvidatsii nedostatkov na proizvodstve," PS, 1940, no. 7, approved for publication April 14, 1940; Pravda, May 30, 1940.

42. Dallin, Sovict Russia's Forcign Policy, pp. 231-33.

43. James Meisal and Edward Kozera, Materials for the Study of the Sovict System (Ann Arbor, 1953), pp. 356-63. Pravda, September 7, 1940.

44. KPSS v resoliutsiiakh ..., vol. 5, p. 432. For Pravda's campaign on the subject see Pravda, August 5, 1940; August 11, 1940; August 15, 1940.

45. A. Leontev, " $\mathrm{Za}$ bol'shevistskii stil' khoziaistvennogo rukovodstva," $P S, 1940$, no. 9; M. Burmistenko, "Partiinaia rabota-osnova nashikh pobed," $P S, 1940$, no. 10. For changes in the definition of pravo kontrolia, cf. A. Tsegolov, "V tsentr vnimaniiavoprosy ekonomiki," $P S, 1940$, no. 11/12, approved for publication July 4, 1940, with F. 
Bol'shevik also changed its orientation. Although it had resumed its campaign for theoretical education of cadres after the war with Finland, it was also obliged to focus on the need for strict labor discipline. ${ }^{46}$

Stalin also apparently decided, in June 1940, to assert full control over the territories assigned to the USSR by the Nazi-Soviet pact. ${ }^{47}$ Zhdanov was dispatched to Estonia to guide its absorption into the USSR and his efforts in this area seemed to improve his standing in Stalin's circle. ${ }^{48}$ But Zhdanov's triumph proved short-lived. In August 1940 the USSR's diplomatic pressure on Rumania produced an intensification of Soviet-German conflict in the Balkans. ${ }^{40}$ The following month the Soviet leadership turned increasingly against Zhdanov's definition of priorities and toward Malenkov's views.

In early September 1940, Zhdanov was replaced as director of agitprop by his deputy G. F. Aleksandrov. Although Zhdanov was said to retain responsibility for "supervision" of agitprop, the change was followed by some indications that the leadership was far less supportive of his views. ${ }^{50}$ Most

Limno and B. Fridland, "Vyshe uroven' khoziaistvennogo rukovodstva," $P S, 1940$, no. 13, approved for publication July 29, 1940. After Pravda's extensive campaign in support of edinonachalic in August, PS belatedly followed suit. See I. Kapustin, "Vsemerno ukrepliat' edinonachalie," $P S, 1940$, no. $15 / 16$; "Gosudarstvennaia i partiinaia distsiplina," $P S$, 1940 , no. 17, approved for publication October 1, 1940 ; "Edinonachalie i pravo kontrolia," $P S, 1940$, no. 18, approved for publication October 21, 1940.

46. In the period between the March CC meeting and the June 26, 1940 decree on labor mobility, Bol'shevik shifted back to its usual position on political education. "Velikii prodolzhatel' dela Marksa Engelsa," Bol'shevik, 1940, no. 7, approved for publication April 20, 1940; "Bol'shevistskuiu propagandu-na vysshuiu stupen'," Bol'shevik, 1940, no. 10, approved for publication June 9, 1940. After the decree, it gave far greater stress to the need for labor discipline in order to "strengthen the state." "Strana sotsializma dol'zhna stat' vo mnogo raz sil'nee i moguchestvennee," Bol'shevik, 1940, no. 11/12, approved for publication July 9, 1940.

47. Dallin, Sovict Russia's Foreign Policy, pp. 233-34.

48. For an authoritative account of Zhdanov's activities in Estonia based on émigré testimony see U.S., Congress, House, Select Committee on Communist Aggression, Report of the Selcet Committe to incestigate Communist aggression and the forced incorporation of the Baltic states into the USSR, 83rd Congress, 2nd Session, 1954 (Washington, D.C., 1954), pp. 245-52. Zhdanov stood between Stalin and Malenkov at the meeting of the Supreme Soviet which approved the absorption of the Baltic states into the USSR. See Pravda, August 2, 1940.

49. Dallin, Soviet Russia's Foreign Policy, pp. 261-67.

50. The personnel change was announced without editorial comment in Pravda, September 7, 1940. Although Pravda recognized that theoretical study was vital for the new citizens of the USSR (see editorial in Pravda, September 20, 1940), the proponents of a more "practical" orientation for agitprop were allowed to express their views at the time of the anniversary of the publication of the Kratkii kurs. M. Kalinin acted as the major spokesman for this group. See his address to the Moscow party organization on October 2, 1940 in M. I. Kalinin, O kommunisticheskom vospitanii $i$ voinskom dolge (Moscow, 1967), pp. 426-44. Moreover, Pravda's editorial on the Kratkii kurs insisted that agitprop work should not be "academic" but directly related to practical problems. Pravda, October 1, 1940. 
important, the Soviet leadership now decided to increase party officials' supervision of industry. On September 26, 1940, the Politburo ordered the first secretaries of local party organizations to turn their attention to industry and transport. ${ }^{51}$ This order was not published at the time, however, and CC publications did not endorse Malenkov's views until after the failure of Soviet diplomatic efforts to stem the deterioration of relations with Germany. In mid-November 1940, V. M. Molotov, the people's commissar for foreign affairs, was sent to Berlin to resolve a series of divisive issues. Soon after the failure of his mission, ${ }^{52} \mathrm{CC}$ publications once again called for greater Secretariat intervention in industry.

In November 1940, the cadres directorate's journal resumed its campaign to extend party officials' "econonic" responsibilities. PS published an article by G. Popov, the leader of the Moscow gorkom which denounced PPOs for their alleged passivity toward factory managers. ${ }^{53}$ PS also gave extremely favorable publicity to the activities of the industrial departments created the previous year. ${ }^{54}$ In December 1940 Pravda indicated that the Soviet leaders had once again endorsed Malenkov's orientation. Pravda's editorial of December 8, 1940 ascribed all industrial success to gorkom leadership and PPO pravo kontrolia, sharply criticized gorkom and obkom officials for their alleged failure to provide "concrete guidance" to enterprises, and failed to endorse the principle of edinonachalie as essential for industrial success. ${ }^{55}$ Two weeks later Pravda announced that the oft-postponed Eighteenth Conference of the VKP(b) would meet in February 1941 to deal with "tasks of Communist party organizations in industry and transport."56

The growing external threat also influenced the leadership's definition of agitprop priorities. In late 1940 Bol'shevik had continued to emphasize the vitality of Marxism-Leninism as a guide to action for all administrative personnel. ${ }^{57}$ But A. S. Shcherbakov's address in January 1941, marking the anniversary of Lenin's death, implied that the agitprop division should devote far more attention to the inculcation of Soviet patriotism. ${ }^{58}$ Bol'shevik im-

51. The Politburo resolution is quoted in Istoriia kommunisticheskoi partii sovctskogo soinia, vol. 5, part 1 (Moscow, 1970), p. 34. An oblique reference to this resolution appeared in Pravda's editorial of October 6, 1940.

52. Dallin, Soviet Russia's Forcign Policy, pp. 270-75.

53. G. Popov, "Partinye organizatsii i tekhnologicheskaia distsiplina na proizvodstve," $P S, 1940$, no. $19 / 20$, pp. 34-38, approved for publication November 4, 1940.

54. A. Rozhkov, "Promyshlennyi otdel obkoma," $P S, 1940$, no. 21, pp. 53-56, approved for publication November 20, 1940.

55. Pravda, December 8,1940 . The emphasis on leadership was in the original.

56. Pravda, December 20, 1940.

57. "Rasshiriat' i uglubliat' propagandu marksizma-leninizma," Bol'shevik, 1940, no. 21, pp. 7-13, approved for publication November 29, 1940.

58. Pravda, January 22, 1941. 
mediately followed suit and once again muted its previous claim that MarxistLeninist theory was the sole basis for correct action. ${ }^{59}$

Malenkov's report to the Eighteenth Conference coupled a sharp critique of the Sovnarkom's industrial administration with an elaborate brief for increased Secretariat supervision and intervention. He asserted that the widespread production failures of the People's Commissariats could be attributed to bureaucratic methods of leadership, ignorance of local economic conditions and administrative personnel, failure to introduce new technology, and immense waste of raw materials. He charged that local party officials had ignored production problems either because they had focused exclusively on agriculture or because they "incorrectly thought that they did not bear responsibility for the work of industry and transport." ${ }^{10}$ Thus Malenkov clearly implied that the Secretariat reform of the Eighteenth Congress had been all too successful in diverting local party officials away from industrial concerns.

Malenkov called for the appointment of "several" secretaries for industry and transport in each gorkom, obkom, kraikom, and CC of republic parties to allow the Secretariat to "share" responsibility for industry with the People's Commissariats. ${ }^{61}$ Although some secretaries had probably been appointed to lead the industrial departments created in November 1939, Malenkov apparently now sought to enlarge their number so that they could replace PPO leaders as the major instrument of supervision of industrial activity. Malenkov did not even mention the PPOs and their pravo kontrolia in his report, and he also explicitly endorsed the principle of edinonachalie. Malenkov's apparent modification of his earlier position may have been designed, in part, to diffuse the Politburo commissars' opposition to his conception of "shared" responsibility for industrial administration.

In fact, there was some evidence of Sovnarkom resistance to any further extension of Secretariat prerogatives in industry. The agenda for the Eighteenth Conference was amended at the last minute to include a report by N. A. Voznesenskii, a vice-chairman of the Sovnarkom and director of Gosplan. Voznesenskii's report emphasized the Sovnarkom's successes in fulfilling the Five-Year Plan and thereby implicitly challenged Malenkov's charge that the Sovnarkom could not meet production targets. Furthermore, while Voznesenskii approved Malenkov's general conclusion that the party organizations had to give "more attention" to problems of industry and trans-

59. "Pod znamenem leninizma," Bol'shevik, 1941, no. 1, pp. 2-5, approved for publication January 30, 1941.

60. G. M. Malenkov, "O zadachakh partiinykh organizatsii $v$ oblasti promyshlennosti i transporta," Bol'shevik, 1941, no. 3/4, p. 15.

61. Ibid., p. 30. 
port, he did not endorse his suggestion that "several" specialized secretaries be appointed at every level of the local party organization. ${ }^{\mathbf{6 2}}$

Zhdanov did not approve of Malenkov's recommendations either. Although he appeared on the rostrum with Stalin and Molotov, ${ }^{63}$ he did not address the Conference, which may be taken to indicate opposition to Malenkov's position. Moreover, A. Kuznetsov, the leader of the Leningrad gorkom, implied that the Politburo had not provided unanimous support for Malenkov's position. ${ }^{64}$ But whatever the extent of opposition from Zhdanov and the Politburo commissars, Malenkov's recommendations were incorporated into the Conference resolution without change. ${ }^{65}$ Immediately after the Conference, Malenkov, Voznesenskii, and Shcherbakov were made candidate-members of the Politburo. ${ }^{68}$

The editorials published in Pravda in the months between the Eighteenth Conference and the German attack on the USSR in June 1941 indicated that the leadership continued to endorse Malenkov's conception of the Secretariat's role. ${ }^{67}$ Pravda briefly criticized the industrial secretaries for overriding the factory managers' prerogatives, ${ }^{68}$ but there was no evidence of sustained support for Zhdanov's orientation during this period.

The Secretariat of the $\mathrm{CC}$ has generally been regarded as the guardian and promulgator of the official version of Soviet ideology. We have seen, however, that Zhdanov and Malenkov each elaborated a variant ideology, one that not only provided guidance for each leader's directorate, but also included a definition of Secretariat leadership. In short, there existed for a period two contending "organizational ideologies" 69 within the Secretariat.

Zhdanov's stress on "consciousness" as the basis for political action and his insistence on the formal study of the texts of Marxism-Leninism provided agitprop officials at every level with a coherent guide to action in dealing with Communists engaged in practical work. On a more fundamental level, Zhdanov's belief that "party-political work" was vital for Secretariat leadership had important implications for party officials' actions.

62. N. A. Voznesenskii, "Khoziaistvennyi itog 1940 i plan razvitiia narodnogo khoziaistva SSSR," Bol'shevik, 1941, no. 3/4.

63. Pravda, February 16, 1941.

64. Pravda, February 18, 1941.

65. KPSS v rezoliutsiiakh ..., vol. 5, pp. $460-70$.

66. Pravda, February 22, 1941.

67. Pravda, February 28, 1941 ; March 7, 1941 ; March 26, 1941 ; May 19, 1941; June 20, 1941.

68. Pravda, April 22, 1941.

69. Franz Schurmann uses this phrase to refer to a "systematic set of ideas with action consequences serving the purpose of creating and using organization." Franz Schurmann, Ideology and Organization in Communist China (New York, 1968), p. 18. 
Zhdanov feared that preoccupation with "economic work" might transform the entire party apparat into merely "another" administrative structure without any special claims for leadership. In Zhdanov's view, Communist Party officials who became preoccupied with production problems would inevitably neglect not only their own theoretical development, but also the recruitment, assignment, education, and monitoring of other party members, eventually becoming indistinguishable from the government officials under their supervision. Focus on "party-political work," however, would protect party officials against any such degeneration. This focus would guarantee officials the proper perspective and the ability to interpret events, while helping them to coordinate a wide range of noneconomic activities.

In contrast, Malenkov's ill-disguised disdain for the study of MarxistLeninist texts, his belief that practice and experience were the only basis for correct action, and his belief that the Secretariat must supply "leadership of the economy" provided local party officials with an ideology that enabled them to supervise, and frequently intervene in, the Sovnarkom's administration of industry.

Malenkov apparently had no qualms about blurring the lines of responsibility between party officials, on the one hand, and Communists who were government bureaucrats, on the other. In fact, he believed that a blurring of authority was essential for effective Secretariat leadership. While Zhdanov implied that the state structure led by the Sovnarkom could operate industry with a minimum of Secretariat intervention, Malenkov insisted that detailed and constant intervention was essential to assure the fulfillment of obligations. What Zhdanov derided as "petty tutelage," Malenkov regarded as "operative management." While Zhdanov believed that preoccupation with "economic work" was a threat to the Secretariat's proper role, Malenkov regarded it as the highest and most important calling of Communist Party officials.

The conflict between these two ideologies was muted during the first months after the German attack on the USSR, but it was revived in 1942-43 and continued until Zhdanov's death in 1948. Although Malenkov was able to resurrect the Secretariat's central "production branch" departments after Zhdanov's death, this organizational change did not end ideological conflict over the proper function of the Secretariat. For example, N. S. Khrushchev's effort to give priority to the Secretariat's "economic work" was resisted by Presidium ministers who sought to preserve the prerogatives of the Council of Ministers and by those CC secretaries who feared an erosion of the Secretariat's "party-political work." Moreover, although Brezhnev does not always use the terminology of his predecessors, his public pronouncements indicate that discord over the Secretariat's proper role continues to plague the Soviet leadership. 